\title{
THE RELATIONSHIP BETWEEN PARENTING STYLES, PERCEIVED SOCIAL SUPPORT AND BULLYING: A CROSS-SECTIONAL RETROSPECTIVE STUDY UPON A SAMPLE OF ROMANIAN STUDENTS
}

\author{
Alina Vlazan, Sebastian Pintea*, \\ Department of Psychology, Babes-Bolyai University, Cluj-Napoca, Romania
}

\begin{abstract}
INTRODUCTION: Based upon the literature on the relationship between parenting styles and bullying and also upon the role of social support, our study aimed at bringing evidence about the relationship between these concepts on a Romanian sample of students.

METHOD: Using a retrospective approach, we investigated 100 students who were asked to remember their high school experience related to bullying, family behaviors, and perceived social support. Our study is a retrospective correlational one. This means that students had to respond to the bullying scale concerning their high school experience, as they remembered it. The questionnaire containing all scales was administered in the online environment. First, participants signed an informed consent and, after that, they received all the items.
\end{abstract}

RESULTS: The permissive style of parenting was negatively and significantly correlated with being a physical victim $(\mathrm{r}=-0.210, \mathrm{p}<0.05)$ and psychological victim $(r=-0.300, p<0.01)$ of bullying. The permissive style was positively and significantly cor- related with family support $(\mathrm{r}=0.483, \mathrm{p}<0.01)$, friends support $(\mathrm{r}=0.276, \mathrm{p}<0.01)$ and significant others' support $(\mathrm{r}=0.366, \mathrm{p}<0.01)$. The only variable with significant gender differences was the verbal aggressor status, with males having a significantly higher level $(\mathrm{M}=4.48, \mathrm{SD}=2.18)$ than females $(\mathrm{M}=3.49, \mathrm{SD}=0.66)$, $\mathrm{t}=-3.202, \mathrm{p}=0.002$.

DISCUSSIONS AND CONCLUSIONS: We found that the permissive and the authoritative/democratic styles of parenting had a protective role against being a bullying victim, while the authoritarian style was associated with a rather high probability of being a victim-aggressor. Second, we found that the permissive and the authoritative/democratic styles were associated with high levels of perceived social support, from all three sources measured, family, friends, and significant others, while the authoritarian style was associated with low levels of social support. Third, we found that perceived social support had a protective role against being a bullying victim. Limits of the study along with its implications for research and practice are also discussed.

Keywords: parenting styles, bullying, social support, gender differences

\footnotetext{
* Corresponding author: Sebastian Pintea, PhD, Department of Psychology, Babes-Bolyai University, 37 Republicii St., 400015, Cluj-Napoca, Romania, Tel./Fax: +40.264.590.967, Email: sebastianpintea@psychology.ro, Web: www.ubbcluj.ro, www.psiedu.ubbcluj.ro

Article received: 20.03 .2021 , accepted: 26.03 .2021 , published: 12.04 .2021

Cite: Vlazan A, Pintea S. The relationship between parenting styles, perceived social support and bullying: a cross-sectional retrospective study upon a sample of romanian students. The Journal of School and University Medicine 2021;VIII(1): 5-13
} 


\section{Introduction}

Nowadays, bullying is a phenomenon largely recognized and with multiple individual and societal implications. In the Romanian context, the researchers and the society in general are just beginning to recognize its magnitude and multiple implications.

The literature defines bullying in terms of aggression upon an individual by being repeatedly exposed to negative actions from one or more individuals [1]. A negative action is a situation in which an individual intentionally generates or intends to generate physical pain or discomfort to another individual, through physical contact, words, or other ways. Other researchers state that bullying does not imply a fight between two individuals of equal power or authority [2]. Also, bullying should not be identified with joking or friendly teasing.

The aggressive behaviors increase in intensity in the middle school and high school periods, and takes various forms such as physical (e.g. hitting, stealing money or other things), verbal (e.g. nicknames, threats), or psychological (e.g. social exclusion, isolation, gossip). The verbal form is more frequently found in 8 to 12 years old children [3], [4], [5]. In schools, bullying appears in places with low monitoring, such as halls or playgrounds.

\section{The bullying aggressor}

The profile of bullying aggressors could vary as a function of the type of bullying behavior they perform. Aggressors are generally aggressive, destructive and find pleasure in dominating others. They tend to have an alert temper, are impulsive, and have low frustration tolerance [6]. Other studies reveal that aggressors have difficulties in processing social information and frequently interpret others' behaviors as antagonistic [7], [8]. They also have a positive attitude toward violence, use aggressiveness to maintain dominance, and prove low levels of empathy. Other researchers reveal that bullying aggressors have a higher probability of smoking and consuming alcohol, have decreased abilities of problem-solving, they externalize their problems, have lower academic performances and they do not like the school environment [9], [10].
Research has proved that frequently, the families of bullying aggressors are problematic [11], [12], [13], [14]. Their parents are generally hostile with them, they reject them or prove indifference. The supervising is minimal and frequently their father is missing. These parents also use physical punishment and anger and frequently punishment is followed by long periods of indifference. Consequently, their children implicitly learn that aggressiveness and violence are acceptable solutions.

Being a bullying aggressor as an adolescent has significant negative consequences upon the mental health in adult life. Researchers found high proportions of attentional deficits, depression, or behavioral disorders among former aggressors [15]. Also, the researchers found low levels of professional performance, high criminal record, and other delinquent activities. Also, bullying aggressors proved later to be aggressive husbands and more likely to use physical punishment with their children [14], which also have a high probability of becoming bullying aggressors themselves.

\section{The bullying victim}

As far as bullying victims are concerned, they are generally less developed physically and less able to defend themselves [8]. They also have anxiety related to their body, the fear of not being hurt, and a negative attitude towards violence. They are frequently less successful in sports and other physical activities [6]. Other studies found that bullying victims have lower communication and problem-solving abilities [16]. Consequently, this kind of child initiates fewer conversations and has lower assertiveness. Also, they have deficitary social and emotional adjustment, difficulties in making friends, and higher feelings of loneliness, but higher abilities in relating with adults. They also have low self-esteem [17]. They perceive themselves as unattractive and insignificant. This mixture of characteristics also explains why frequently they do not report bullying behaviors and also why their aggressors repeat their aggressions. They have generally good academic performance but it decreases as they become adults.

Generally, bullying victims' families tend to become overprotective as they realize the vulnerabil- 
ity and the anxiety of their children. They also avoid conflicts, considering that their children could not deal with conflict.

Being a bullying victim has both short and longterm negative effects. In a short term, some studies revealed that the former victim status correlates with anxiety and depression [18], [19]. This correlation was even higher for female adolescents with consequences upon eating disorders [20]. Higher levels of attentional deficits were also revealed among former bullying victims [15]. Other consequences proved by research are low academic performance, increased fear, loneliness, feelings of abandonment, and suicidal ideation [21] and somatization (e.g. headaches when being at school), sleep disorders, and even suicide [18], [8]. In a long term, as adults, former bullying victims prove mental health problems, inhibition toward their partner, or revenge upon their former bullying aggressor [11], [22] [8]. As parents, former victims tend to be overprotective themselves and consequently having bullying-vulnerable children [8].

Based upon all these results, we can conclude that the family environment and ultimately the way parents interact with their children has a lot to do with the bullying phenomenon [23]. The analysis of the relationship between family and bullying starts with the influence of attachment upon children's sociability and the social support they receive. Many studies from this category relate bullying with parenting [24]. The literature describes 3 parenting styles: authoritative (democratic), authoritarian, and permissive/indulgent [25]. In the authoritative style parents guide the activities of their children rationally, problem-oriented, they exert control when it is necessary and give their children the liberty to take action responsibly and independently. Parents pay attention to their kids and explain to them the reasons behind the rules that they have to follow. According to the literature [26] authoritative parents establish clear expectations and set high standards for their children but they also monitor their behavior using rational control. They also encourage their children to make decisions and to learn from their mistakes. This kind of parents treats their children with warmth, respect, and affection. Researchers found that adolescents with authoritative parents are more likely to be socially competent, responsible, and autonomous [27]. Authoritarian parents are those who try to modulate, control, and evaluate their children's behavior without taking into account their feelings. Under this parenting style, children are asked to follow rules without any other explanation. This kind of parents is generally overdemanding while they neglect their responsibilities regarding their children, being also extremely strict and controlling, dictating without asking opinions. Researchers found that adolescents with authoritarian parents tend to become rebels, aggressive, and dependent upon their parents [27]. The permissive parents are non-punitive and have positive relationships with their children. They have low or no demands from their kids, let them behave as they wish, they are warm, indulgent, and passive [27]. They show their love by offering their children the freedom to behave as they want, without taking into account the consequences. They do not set limits even when the safety of their children is in danger [26].

There are a plethora of studies regarding the relationship between parenting style and both bullying aggressors and victims. Several of them found that the aggressiveness of children is related to parenting [28], [29] and also that parental low supervision and monitoring, taught disciplinary methods, inconsistencies between parents, rejection, and low involvement correlate with children's behavioral problems [30], [31]. Generally, bullying aggressors learn aggressiveness in their families [28] and tend to resolve their problems by violence [1]. The bullying aggressors feel isolated and rejected at home and consequently search to affiliate with certain groups at school. They do not feel in control at home and consequently, they try to control and harm others at school. Several studies found that affiliation need is more important for girls and the need for power is more important for boys [32], [33]. As far as bullying victims are concerned, researchers found that male bullying victims had overprotective mothers [1]. Other researchers [34] found a correlation between bullying victims and dysfunctional family relationships, especially for girls. There is evidence that children with overprotective families develop characteristics that attract bullying aggressions and a low capacity to defend themselves against bullying [35]. Other studies identify that many of the parents with children that are bullying victims are former bullying victims themselves [8]. Finally, some studies reveal a relationship between permissive 
parenting style and bullying victims [36] or difficulties to control aggressive impulses [37].

An important role in this context is played by social support. Researchers found that bullying victims report less social support from teachers and peers than non-victims do [38]. This result was confirmed by another study [39] which found that children who were bullying victims of aggressors/victims perceived they received less social support from their peers than other children. Other researchers revealed that victims who experienced aggression for more than 4 weeks, reported that they requested social support to a lower extent [40]. Another study [41] found that victimizing was related to externalization problems only for adolescents who perceived a low level of social support. Literature also revealed that adolescents who perceived a low level of social support had also internalization problems [42].

Based upon these premises, and also upon the fact that bullying research on Romanian population is only beginning to develop, our study aims at exploring the relationship of bullying status (victim and aggressor) with parenting styles and also with perceived support in a Romanian sample of students. Our study retrospectively investigates these relations by asking students to remember their high school bullying experiences and also the parenting practices in their families, along with the social support they perceived in that period of their life. Also, we were interested in exploring possible gender differences regarding all three concepts measured.

\section{Method}

\section{Participants}

There were 100 voluntary students enrolled in our study, with an age between 18 and 25 . The sample included 44 men and 57 women. Regarding their marital status, $94.2 \%$ were not married and $5.8 \%$ were married. Most of them came from a biparental family (90.3\%) while only $9.7 \%$ came from a monoparental family. Of the total sample, $50.5 \%$ of the participants were employed. They perceived their income as low $(53.9 \%)$, average $(34.3 \%)$, or high $(11.8 \%)$.

\section{Instruments}

Bullying was measured using a short version (28 items) of the Olweus Bullying Questionnaire -
OBQ [43]. This instrument incorporates 42 items and measures both bully and victim status. Each item describes a different behavior, and the participants are asked to determine the frequency with which this behavior occurred over the past two months. The frequency is measured with 4 points Likert scales. The short version proved a good internal consistency $(\alpha$ over 0.80 ) and good construct validity.

The pareting styles were measured with The Parental Authority Questionnaire - PAQ [44]. It consists of 30 items per parent and yields permissive, authoritarian, and authoritative scores for both the mother and the father. The items were constructed based upon the descriptions proposed by Baumrind [45]. Each item represents a specific parenting behavior of the parent that the respondent should recognize on five points Likert scale ( $1=$ strongly disagree to $5=$ strongly agree). The original consistencies of the subscale ranged from 0.77 to 0.92 .

The perceived social support was measured by The Multidimensional Scale of Perceived Social Support - MSPSS [46]. It is a self-report instrument incorporating 12 items and measuring three different sources of support: family, friends, and significant others. Each item was rated on a 5-point Likert-type scale ranging from strongly disagree (1) to strongly agree (5). The original internal consistency of the subscales varied from 0.85 to 0.91 . The literature generally confirms good factorial and construct validity and high reliability of this scale.

\section{Design and procedures}

Our study is a retrospective correlational one. This means that students had to respond to the bullying scale concerning their high school experience, as they remembered it. The questionnaire containing all scales was administered in the online environment. First, participants signed informed consent and after that, they received all the items. The completion of the questionnaire took around 25 minutes.

\section{Results}

In the first step of our analysis, we investigated the correlation between the parenting styles and the bullying status of the participants. Results are presented in table 1. 
Tabel 1. The correlation matrix between perceived parenting styles and bullying status

\begin{tabular}{|c|c|c|c|c|c|c|c|c|}
\hline Variables & 1 & 2 & 3 & 4 & 5 & 6 & 7 & 8 \\
\hline 1.Permissive style & - & & & & & & & \\
\hline 2.Authoritarian style & $-.558^{* *}$ & - & & & & & & \\
\hline 3.Authoritative style & $.527^{* *}$ & $-.542 * *$ & - & & & & & \\
\hline 4.Physical victim & $-.210 *$ & $.371 * *$ & $-.370 * *$ & - & & & & \\
\hline 5.Verbal victim & -.188 & $.228^{*}$ & $-.295 * *$ & $.505 * *$ & - & & & \\
\hline 6.Psychological victim & $-.300^{* *}$ & $.294 * *$ & $-.411 * *$ & $.429 * *$ & $.516^{* *}$ & - & & \\
\hline 7.Physical aggressor & -.053 & .204 & -.044 & $.362 * *$ & .075 & .030 & - & . \\
\hline 8.Verbal aggressor & -.067 & .165 & -.003 & $.232 *$ & .110 & .012 & $.577 * *$ & - \\
\hline 9.Psychological aggressor & -.155 & .202 & -.167 & .199 & .110 & .092 & $.432 * *$ & $.368^{* *}$ \\
\hline
\end{tabular}

$\mathrm{N}=100,{ }^{*} \mathrm{p}<0.05, * * \mathrm{p}<0.01$

As table 1 shows, the permissive style of parenting was negatively and significantly correlated with being a physical victim $(\mathrm{r}=-0.210, \mathrm{p}<0.05)$ and psychological victim $(r=-0.300, p<0.01)$ of bullying. Both correlations were low to moderate in magnitude. The authoritarian style was positively and significantly correlated with being a physical $(\mathrm{r}=0.371$, $\mathrm{p}<0.01)$, verbal $(\mathrm{r}=0.228, \mathrm{p}<0.05)$ and psychological $(\mathrm{r}=0.294, \mathrm{p}<0.01)$ victim of bullying. Correlations magnitude varied from low to moderate. The author- itative style negatively and significantly correlated with being a physical $(\mathrm{r}=-0.370, \mathrm{p}<0.01)$, verbal $(\mathrm{r}=-$ $0.295, \mathrm{p}<0.01)$ and psychological $(\mathrm{r}=-0.411)$ victim of bullying. All three correlations were of moderate intensities.

In the next step of our analysis we analyzed the correlations between the perceived parenting styles and the perceived social support. Results are presented in table 2.

Table 2. The correlation matrix between perceived parenting styles and perceived social support

\begin{tabular}{|l|l|l|l|l|l|l|}
\hline \multicolumn{2}{|c|}{ Variables } & \multicolumn{1}{c|}{$\mathbf{1}$} & \multicolumn{1}{c|}{$\mathbf{2}$} & \multicolumn{1}{c|}{$\mathbf{3}$} & \multicolumn{1}{c|}{$\mathbf{4}$} & \multicolumn{1}{c|}{$\mathbf{5}$} \\
\hline 1.Permissive style & & - & & & & \\
\hline 2.Authority style & & $-.558^{* *}$ & - & & & \\
\hline 3.Authoritative style & & $.527^{* *}$ & $-.542^{* *}$ & - & & \\
\hline 4.Family support & & $.483^{* *}$ & $-.545^{* *}$ & $.813^{* *}$ & - & \\
\hline 5.Friends support & & $.276^{* *}$ & $-.230^{*}$ & $.440^{* *}$ & $.423^{* *}$ & - \\
\hline 6.Others support & & $.366^{* *}$ & $-.325^{* *}$ & $.575^{* *}$ & $.673^{* *}$ & $.671^{* *}$ \\
\hline
\end{tabular}

$\mathrm{N}=100,{ }^{*} \mathrm{p}<0.05, * * \mathrm{p}<0.01$

As table 2 shows, the permissive style was positively and significantly correlated with family support $(\mathrm{r}=0.483, \mathrm{p}<0.01)$, friends support $(\mathrm{r}=0.276, \mathrm{p}<0.01)$ and significant others support $(\mathrm{r}=0.366, \mathrm{p}<0.01)$. All three correlations were of moderate intensities. The authoritarian style was negatively and significantly correlated with family support $(\mathrm{r}=-0.545, \mathrm{p}<0.01)$, friends support $(\mathrm{r}=-0.230, \mathrm{p}<0.05)$ and significant others support $(\mathrm{r}=-0.325, \mathrm{p}<0.01)$. The correlations recorded moderate to high magnitudes. The authoritative style was positively and significantly correlated with family support $(\mathrm{r}=0.813, \mathrm{p}<0.01)$, friends support $(\mathrm{r}=0.440, \mathrm{p}<0.01)$ and significant others support $(r=0.575, p<0.01)$. Correlations varied from moderate to large intensities.

Further on, we analyzed the correlations between different types of social support and the bullying status. Results are presented in table 3. 
Journal of School and University Medicine

Table 3. The correlation matrix between perceived social support and bullying status

\begin{tabular}{lllllllll}
\hline \multicolumn{1}{c}{ Variables } & \multicolumn{1}{c}{$\mathbf{1}$} & $\mathbf{2}$ & $\mathbf{3}$ & $\mathbf{4}$ & $\mathbf{5}$ & $\mathbf{6}$ & $\mathbf{7}$ & $\mathbf{8}$ \\
\hline 1.Family support & - & & & & & & & \\
2.Friends support & $.423^{* *}$ & - & & & & & & \\
3.Others support & $.673^{* *}$ & $.671^{* *}$ & - & & & & & \\
4.Physical victim & $-.282^{* *}$ & $-.249^{*}$ & -.187 & - & & & & \\
5.Verbal victim & $-.239^{*}$ & -.172 & -.084 & $.505^{* *}$ & - & & & \\
6.Psychological victim & $-.291^{* *}$ & $-.436^{* *}$ & $-.397^{* *}$ & $.429^{* *}$ & $.516^{* *}$ & - & & \\
7.Physical aggressor & -.075 & .133 & .007 & $.362^{* *}$ & .075 & .030 & - & \\
8.Verbal aggressor & -.070 & .148 & .067 & $.232^{*}$ & .110 & .012 & $.577^{* *}$ & - \\
9.Psychological aggressor & -.137 & .083 & .002 & .199 & .110 & .092 & $.432^{* *}$ & $.368^{* *}$ \\
\hline
\end{tabular}

$\mathrm{N}=100,{ }^{*} \mathrm{p}<0.05, * * \mathrm{p}<0.01$

As table 3 shows, family support was negatively low to moderate intensities. Significant others' support and significantly correlated with being a physical $(\mathrm{r}=-$ was negatively and significantly correlated with being $0.282, \mathrm{p}<0.01)$, verbal $(\mathrm{r}=-0.239, \mathrm{p}<0.05)$ and $\mathrm{psy}-$ a psychological victim of bullying $(\mathrm{r}=-0.397, \mathrm{p}<0.01)$, chological $(\mathrm{r}=-0.291, \mathrm{p}<0.01)$ victim of bullying. All with moderate intensity.

correlations had low to moderate magnitudes. Friends In the final step of our analysis we investigated support was negatively correlated with being physi- if there were any differences in parenting styles, percal $(\mathrm{r}=-0.249, \mathrm{p}<0.05)$ and psychological $(\mathrm{r}=-0.436$, ceived social support, and bullying status as a function $\mathrm{p}<0.01$ ) victim of bullying. Correlations varied from of gender. Results are presented in table 4.

Table 4. Gender differences regarding perceived parental styles, social support, and bullying status

\begin{tabular}{|c|c|c|c|c|c|c|}
\hline & Gender & $\mathbf{N}$ & $\mathbf{M}$ & SD & $\mathrm{t}$ & $\underline{\mathbf{p}}$ \\
\hline \multirow{2}{*}{ Permissive style } & \multirow{2}{*}{$\begin{array}{l}\text { Female } \\
\text { Male }\end{array}$} & 57 & \multirow{2}{*}{\begin{tabular}{|l|}
30.38 \\
30.53
\end{tabular}} & 6.22 & \multirow[t]{2}{*}{-.119} & .905 \\
\hline & & 44 & & 6.14 & & \\
\hline \multirow{2}{*}{ Authoritarian style } & \multirow{2}{*}{$\begin{array}{l}\text { Female } \\
\text { Male }\end{array}$} & 57 & \multirow{2}{*}{\begin{tabular}{|l|}
25.50 \\
25.32
\end{tabular}} & 9.74 & \multirow[t]{2}{*}{.092} & .927 \\
\hline & & 44 & & 9.66 & & \\
\hline \multirow{2}{*}{ Authoritative style } & \multirow{2}{*}{$\begin{array}{l}\text { Female } \\
\text { Male }\end{array}$} & 57 & \multirow{2}{*}{\begin{tabular}{|l|}
34.05 \\
34.28
\end{tabular}} & 9.03 & \multirow[t]{2}{*}{-.127} & .899 \\
\hline & & 44 & & 8.93 & & \\
\hline \multirow{2}{*}{ Family support } & \multirow{2}{*}{$\begin{array}{l}\text { Female } \\
\text { Male }\end{array}$} & 57 & \multirow{2}{*}{$\begin{array}{l}20.35 \\
21.16 \\
\end{array}$} & 6.44 & \multirow{2}{*}{-.606} & .546 \\
\hline & & 44 & & 6.87 & & \\
\hline \multirow{2}{*}{ Friends support } & \multirow{2}{*}{$\begin{array}{l}\text { Female } \\
\text { Male }\end{array}$} & 57 & \multirow{2}{*}{$\begin{array}{l}20.31 \\
20.37\end{array}$} & 6.86 & \multirow[t]{2}{*}{-.040} & .968 \\
\hline & & 44 & & 7.09 & & \\
\hline \multirow{2}{*}{ Others support } & \multirow{2}{*}{$\begin{array}{l}\text { Female } \\
\text { Male }\end{array}$} & 57 & \multirow{2}{*}{$\begin{array}{l}22.17 \\
20.09\end{array}$} & 6.08 & \multirow[t]{2}{*}{1.572} & .119 \\
\hline & & 44 & & 7.14 & & \\
\hline \multirow{2}{*}{ Physical victim } & \multirow{2}{*}{$\begin{array}{l}\text { Female } \\
\text { Male }\end{array}$} & 57 & \multirow{2}{*}{$\begin{array}{l}5.40 \\
5.61 \\
\end{array}$} & 1.51 & \multirow[t]{2}{*}{-.568} & .571 \\
\hline & & 44 & & 2.20 & & \\
\hline \multirow{2}{*}{ Verbal victim } & \multirow{2}{*}{$\begin{array}{l}\text { Female } \\
\text { Male }\end{array}$} & 57 & \multirow{2}{*}{$\begin{array}{l}4.75 \\
4.04\end{array}$} & 2.37 & \multirow[t]{2}{*}{1.722} & .088 \\
\hline & & 44 & & 1.47 & & \\
\hline \multirow{2}{*}{ Psychological victim } & \multirow{2}{*}{$\begin{array}{l}\text { Female } \\
\text { Male }\end{array}$} & 57 & \multirow{2}{*}{$\begin{array}{l}3.52 \\
3.36\end{array}$} & 1.63 & \multirow[t]{2}{*}{.512} & .610 \\
\hline & & 44 & & 1.51 & & \\
\hline
\end{tabular}


Scientific Articles

\begin{tabular}{|c|c|c|c|c|c|c|}
\hline & Gender & $\mathbf{N}$ & $\mathbf{M}$ & SD & $\mathrm{t}$ & $\underline{p}$ \\
\hline \multirow[t]{2}{*}{ Physical aggressor } & \multirow{2}{*}{\begin{tabular}{|l|} 
Female \\
Male
\end{tabular}} & 57 & \multirow{2}{*}{$\begin{array}{l}4.69 \\
5.17\end{array}$} & 1.02 & \multirow[t]{2}{*}{-1.815} & .073 \\
\hline & & 44 & & 1.54 & & \\
\hline \multirow[t]{2}{*}{ Verbal aggresor } & \multirow{2}{*}{$\begin{array}{l}\text { Female } \\
\text { Male }\end{array}$} & 57 & \multirow{2}{*}{$\begin{array}{l}3.49 \\
4.48 \\
\end{array}$} & .66 & \multirow[t]{2}{*}{-3.202} & .002 \\
\hline & & 44 & & 2.18 & & \\
\hline \multirow[t]{2}{*}{ Psychological aggressor } & Female & 57 & 2.91 & 1.22 & .477 & .634 \\
\hline & Male & 44 & 2.78 & 1.45 & & \\
\hline
\end{tabular}

As table 4 shows, the only variable with significant gender differences was the verbal aggressor status, with males having a significantly higher level $(\mathrm{M}=4.48, \mathrm{SD}=2.18)$ than females $(\mathrm{M}=3.49, \mathrm{SD}=0.66)$, $\mathrm{t}=-3.202, \mathrm{p}=0.002$.

\section{Discussion and conclusions}

Based upon the literature on the relationship between parenting styles and bullying and also upon the role of social support, our study aimed at bringing evidence about the relationship between these concepts on a Romanian sample of students. Using a retrospective approach, we investigated 100 students who were asked to remember their high school experience related to bullying, family behaviors, and perceived social support.

First, our results confirm the relationship between the parenting styles and the bullying-victim status. We found that the permissive and the authoritative/democratic styles of parenting had a protective role against being a bullying victim, while the authoritarian style was associated with a rather high probability of being such a victim. While the first finding is congruent with the existing literature, this last result seems rather counterintuitive. Literature indicates that the authoritarian style would be positively associated with being a bullying aggressor and not a victim. Still, if we analyze the non-significant correlations with the aggressor status (verbal, psychological, and physical) and focus on the magnitude of effects, we can observe low to moderate intensities from 0.16 to 0.20 , which means that there is a relationship there but it could not be revealed as significant because of the relatively low statistical power generated by the small volume of participants. Also, taking into account some positive correlations between being a victim and being an aggressor (e.g. $r=0.362$ for physical victim/aggressor) we can conclude that the authoritarian style can be treated as a vulnerability for being a bullying aggressor with a higher probability for victim/aggressor status.

Second, we found that the permissive and the authoritative (democratic) styles were associated with high levels of perceived social support, from all three sources, measured, family, friends, and significant others, while the authoritarian style was associated with low levels of social support. These results confirm once more the dysfunctional consequences of the authoritarian style of parenting. The low social support perceived by individuals raized with an authoritarian style is associated not just with being a bullying aggressor, as we previously mentioned but also with low well-being [47], [48], unhealthy coping strategies [49], [50], and generally with low social and psychological functioning [51].

Third, we found that all three types of perceived social support (family, friends, and significant others) have a protective role against the bullying victim status. The explanation of these results is probably related to the role of social support in improving the coping strategies used against bullying and also its role in inhibiting the perceived consequences of being a bullying victim.

Finally, we found that there were generally no gender differences regarding the parenting styles, the perceived social support, and bullying status, except for verbal aggressor status which had a higher level for males. This means that generally both genders benefit to a high degree from being raised with less authoritative styles and both perceive high levels of social support from these parenting styles which further protect them from being bullying victims. 
Our study has also several limits for which the authors take full responsibility. First, we used a cross-sectional approach which allowed just to identification relations between variables, without any direct proof for causality. Second, we used a retrospective approach, investigating the highschool experience of present students, which could have biased the actual phenomenon investigated by certain memory limits. Last but not least, our sample was relatively small, which generated, as we have previously underlined, a certain limit regarding the statistical power.

Beyond these limits, taking into account all the results revealed by our study, we can conclude that it brings a valuable input not just for the general importance of raising children with democratic and non-authoritarian styles, but also for the ways children and adolescents can be protected against being bullying victims.

\section{References}

1. Olweus D. Bully/victim problems among schoolchildren: Basic facts and effects of a school-based intervention program. The development and treatment of childhood aggression. 1991;17:411-448.

https://www.researchgate.net/publication/245590401_ Bullyvictim_problems_among_school_children_Basic_facts_ and_effects_of_a_school_based_intervention

2. Craig W, Harel-Fisch Y, Fogel-Grinvald H, Dostaler S, Hetland J, Simons-Morton B, Pickett W. A cross-national profile of bullying and victimization among adolescents in 40 countries. International journal of public health. 2009;54(2):216-224. DOI: 10.1007/s00038-009-5413-9

3. Baldry AC, Farrington DP. Parenting influences on bullying and victimization. Legal and Criminological Psychology. 1998;3(2):237-254. https://doi.org/10.1111/j.2044-8333.1998. tb00364.x

4. O’Moore AM, Kirkham C, Smith M. Bullying behavior in Irish schools: A nationwide study. The Irish Journal of Psychology. 1997;18(2):141-169. https://doi.org/10.1080/03033910. 1997.10558137

5. Whitney I, Smith PK. A survey of the nature and extent of bullying in junior/middle and secondary schools. Educational research. 1993;35(1):3-25. https://doi. org $/ 10.1080 / 0013188930350101$

6. Olweus D. Victimization by peers: Antecedents and long-term outcomes. Social withdrawal, inhibition, and shyness in childhood. 1993;315-341.

7. Dodge KA. Emotion and social information processing. In J. Garber \& K. A. Dodge (Eds.), The development of emotion regulation and dysregulation. New York: Cambridge University Press. 1991;159-181.
8. McNamara BE, McNamara FJ. Keys to Dealing with Bullies. Barron's Parenting Keys. Barron's Educational Series, Inc., 250 Wireless Boulevard, Hauppage, NY 11788. 1997.

9. Nansel TR, Overpeck M, Pilla RS, Ruan WJ, Simons-Morton B, Scheidt P. Bullying behaviors among US youth: Prevalence and association with psychosocial adjustment. JAMA. 2001;285:2094-2110. DOI: 10.1001/jama.285.16.2094

10. Andreou E. Bully/victim problems and their association with coping behavior in conflictual peer interactions among school-age children. Educational Psychology. 2001;21:59- 66. DOI: $10.1080 / 01443410125042$

11. Carney AG Merrell KW. Bullying in schools: Perspectives on understanding and preventing an international problem. School Psychology International. 2001;22:364-382. https:// doi.org/10.1177/0143034301223011

12. Curtner-Smith ME. Mechanisms by which family processes contribute to school-age boys' bullying. Child Study Journal. 2000;30:169-187.

13. Olweus D. Annotation: Bullying at school: Basic facts and effects of a school-based intervention program. Journal of Child Psychology and Psychiatry and Allied Disciplines. 1994;35:1171-1190. DOI: 10.1111/j.1469-7610.1994.tb01229.x

14. Roberts WB. The bully as a victim. Professional School Counseling. 2000;4:148-156.

15. Kumpulainen K, Räsänen E, Puura K. Psychiatric disorders and the use of mental health services among children involved in bullying. Aggressive Behavior. 2001;27(2):102-110. DOI: $10.1002 / a b .3$

16. Glew G, Rivara F, Feudtner C. Bullying: Children hurting children. Pediatrics in Review. 2000; 21:183-190. DOI: 10.1542/pir.21-6-183

17. O'Moore M, Kirkham C. Self-esteem and its relationship to bullying behavior. Aggressive behavior. 2001;27(4):269283. DOI: $10.1002 / \mathrm{ab} .1010$

18. Brockenbrough KK, Cornell DG, Loper AB. Aggressive attitudes among victims of violence at school. Education \& Treatment of Children. 2002;25:273-287.

19. Kaltiala-Heino R, Rimpela PR, Rimpela A. Bullying at school: An indicator of adolescents at risk for mental disorders. Journal of Adolescence.2000;23:661-674. https://doi. org/10.1006/jado.2000.0351

20. Bond L, Carlin JB, Thomas L, Rubin K, Patton G. Does bullying cause emotional problems? A prospective study of young teenagers. Bmj. 2001;323(7311):480-484. doi: 10.1136/ bmj.323.7311.480

21. Beale AV. "Bullybusters": Using drama to empower students to take a stand against bullying behavior. Professional School Counseling. 2001;4(4):300.

22. Gilmartin BG. Peer group antecedents of severe love-shyness in males. Journal of personality. 1987;55(3):467489. DOI: 10.1111/j.1467-6494.1987.tb00447.x

23. Yubero S, Larra naga E, Martínez I. Familia, comunicación y conductas de acoso. In A. Ovejero, P. K. Smith, \& S. Yubero (Eds.), El acoso escolar ysu prevención: Perspectivas internacionales. Madrid: Biblioteca Nueva. 2013.

24. Nickerson AB, Mele D, Osborne-Oliver KM. Parentchild relationships and bullying. In S. R. Jimerson, S. M. Swearer, \& D. L. Espelage (Eds.), Handbook of bullying in schools. An 
international perspective. New York; London: Routledge. 2010:187-197.

25. Baumrind D. The influence of parenting style on adolescent competence and substance use. The Journal of Early Adolescence. 1991;11(1):56-95. https://doi. org $/ 10.1177 / 0272431691111004$.

26. Greenwood B. The Baumrind theory of parenting styles. GlobalPost-International News. Retrieved December 15, 2013, from everyday.globalpost.com/baumrindtheory- parenting-styles-6147.html

27. Kopko K. Parenting styles and adolescents. Cornell University Cooperative Extension. 2007. Retrieved August 15, 2013, from http//.www.parenting.cit.cornel.edu.

28. Eron LD, Huesmann LR. The stability of aggressive behavior - even unto the third generation. In Handbook of developmental psychopathology. Springer, Boston, MA. 1990:147156.

29. Garnefski N, Okma S. (1996). Addiction-risk and aggressive/criminal behavior in adolescence: Influence of family, school, and peers. Journal of adolescence. 1996;19(6):503-512. DOI: $10.1006 /$ jado.1996.0049

30. Loeber R., Hay D. Key issues in the development of aggression and violence from childhood to early adulthood. Annual review of psychology.1997; 48(1):371-410. DOI: 10.1146/ annurev.psych.48.1.371

31. Loeber R, Stouthamer-Loeber M. Family factors as correlates and predictors of juvenile conduct problems and delinquency. In M. Tonry, \& N. Morris (Eds.), Crime and justice. Chicago, IL: University of Chicago Press. 1986:29-149.

32. Lane DA. Bullying in school: The need for an integrated approach. School Psychology International. 1989;10(3):211-215. https://doi.org/10.1177/0143034389103007

33. O'Moore AM, Hillery B. (1989). Bullying in Dublin schools. The Irish Journal of Psychology. 1989;10(3):426-441. DOI:10.1080/03033910.1989.10557759

34. Rigby K. School children's perceptions of their families and parents as a function of peer relations.Journal of Genetic Psychology.1993;154:501-513. https://doi.org/10.1080/0022132 5.1993 .9914748

35. Stevens V, De Bourdeaudhuij I, Van Oost P. Relationship of the family environment to children's involvement in bully/ victim problems at school. Journal of Youth and Adolescence. 2002;31(6):419-428. DOI:10.1023/A:1020207003027

36. Baldry AC, Farrington DP. Bullies and delinquents: Personal characteristics and parental styles. Journal of Community \& Applied Social Psychology.2000;10:17-31.

37. Miller JM, Diiorio C, Dudley W. Parenting style and adolescent's reaction to conflict: Is there a relationship? Journal of Adolescent Health. 2002;31(6):463-468. DOI: 10.1016/s1054$139 x(02) 00452-4$

38. Furlong MJ, Chung A, Bates M, Morrison RL. Who are the victims of school violence? A comparison of student non-victims and multi-victims. Education and Treatment of Children. 1995: 282-298.

39. Demaray MK, Malecki CK. Perceptions of the frequency and importance of social support by students classified as victims, bullies, and bully/victims in an urban middle school. School Psychology Review. 2003;32(3):471-490. https://doi.org/ 10.1080/02796015.2003.12086213

40. Hunter SC, Boyle JM. Appraisal and coping strategy use in victims of school bullying. British Journal of Educational Psychology. 2004;74(1):83-107. DOI: 10.1348/000709904322848833

41. Prinstein MJ, Boergers J, Vernberg EM. Overt and relational aggression in adolescents: Social-psychological adjustment of aggressors and victims. Journal of clinical child psychology. 2001; 30(4): 479-491. DOI: 10.1207/S15374424JCCP3004_05

42. Hodges EV, Boivin M, Vitaro F, Bukowski WM. The power of friendship: protection against an escalating cycle of peer victimization. Developmental psychology. 1999;35(1):94.

43. Olweus D. Olweus Bullying Questionnaire. Center City, MN: Hazelden. 2007.

44. Buri JR. Parental Authority Questionnaire. Journal of Personality Assessment.1991;57(1): 110-119. https://doi. org/10.1207/s15327752jpa5701_13

45. Baumrind D. Current patterns of parental authority. Developmental Psychology Monographs. 1971;4:2.

46. Zimet GD, Dahlem NW, Zimet SG, Farley GK. The multidimensional scale of perceived social support. Journal of personality assessment. 1988;52(1):30-41. DOI: 10.1207/ s15327752jpa5201_2

47. House JS, Landis KR, Umberson D. Social relationships and health. Science.1988;241(4865):540-545. DOI: 10.1126/science.3399889

48. Sarason BR, Sarason IG, Pierce GR. Social support: An interactional view. John Wiley \& Sons. 1990

49. Cohen S. Social relationships and health. American psychologist. 2004;59(8):676. DOI: 10.1037/0003-066X.59.8.676

50. Cohen S, Wills TA. Stress, social support, and the buffering hypothesis. Psychological Bulletin. 1985;98(2):310.

51 Caplan G. Support systems and community mental health: Lectures on concept development. Behavioral publications. 1974. 